\title{
RATIONAL EMOTIVE BEHAVIOR THERAPY SEBAGAI UPAYA MENINGKATKAN KUALITAS HIDUP PENDERITA DIABETES MELLITUS
}

\section{RATIONAL EMOTIVE BEHAVIOR THERAPY EFFORTS TO IMPROVE THE QUALITY OF LIFE AMONG DIABETES MELLITUS PATIENTS}

\author{
Rr. Dwi Astuti \\ H. Fuad Nashori, \\ RA. Retno Kumolohadi \\ Fakultas Psikologi dan IImu Sosial Budaya, Universitas Islam Indonesia Yogyakarta \\ Email: wiwik.psi@gmail.com
}

\begin{abstract}
Patients with diabetes mellitus decreased quality of life associated with the complications posed by the disease. Quality of life can also be used as a parameter related to the impact the handling of patient treatment that has been done. The purpose of this research was to understand the effectiveness of rational emotive behavior therapy in improving the quality of life of people with diabetes mellitus with diabetic patients' expectations can manage diabetes mellitus mellitus and live better. The method used quasi-experimental method. All subjects were given the scale of quality of life of diabetes mellitus DQOLCTQ-R. Then the experimental group was given 12 times season REBT. Then there was a posttest to see impact of REBT on experimental group. The subjects in this study 7 people for the experimental group and 7 for the control group. the was a significant difference between the quality of life of people with diabetes mellitus when administered before the intervention and after obtaining the intervention of rational emotive behavior therapy. This is indicated by the $z=-3.071$ with $p=0.002$, for $p<0.05$ with a significance level of $5 \%$. This concluded that REBT can improve the quality of life in patients with diabetes mellitus.. Quality of life scores of the experimental group is higher than the score of quality of life of the control group.
\end{abstract}

Keywords: rational emotive behavior therapy, quality of life, diabetes mellitus 


\begin{abstract}
ABSTRAK
Penderita diabetes mellitus mengalami penurunan kualitas hidup terkait dengan komplikasi yang ditimbulkan oleh penyakit tersebut. Kualitas hidup dapat digunakan sebagai parameter penanganan terhadap pasien terkait dampak pengobatan yang telah dilakukan. Tujuan dari penelitian ini adalah untuk mengetahui secara empirik efektivitas Rational Emotive Behavior Therapy (REBT) dalam meningkatkan kualitas hidup penderita diabetes mellitus dengan harapan pasien diabetes mellitus dapat mengelola diabetes mellitus dan hidup lebih baik. Metode penelitian ini menggunakan kuasi eksperimen. Semua subjek (7 orang untuk kelompok eksperimen dan 7 orang untuk kelompok kontrol) diberikan skala kualitas hidup diabetes mellitus DQOLCTQ-R. Kelompok eksperimen diberikan REBT selama 12 kali pertemuan dan pascates untuk melihat dampak REBT yang diberikan pada kelompok ekspermen. Sementara hasil penelitian menunjukkan ada perbedaan yang signifikan antara kualitas hidup penderita diabetes mellitus saat sebelum diberikan intervensi dan setelah mendapatkan intervensi dengan hasil $z=-3,071$ dengan $p=0,002$, karena $p<0,05$ dengan taraf signifikansi $5 \%$. Simpulannya adalah ada perbedaan yang signifikan antara skor kualitas hidup kelompok eksperimen dengan skor kualitas hidup kelompok kontrol pada subjek penelitian. Skor kualitas hidup kelompok eksperimen lebih tinggi dari pada skor kualitas hidup kelompok kontrol. REBT dapat meningkatkan kualitas hidup pada penderita diabetes mellitus.
\end{abstract}

Kata kunci: Kualitas hidup, Rational Emotive Behavior Therapy, Diabetes Mellitus

Menurut data Organisasi Kesehatan Dunia (WHO), Indonesia menempati urutan keenam di dunia sebagai negara dengan jumlah penderita Diabetes Mellitus (DM) terbanyak setelah India, Cina, Rusia, Jepang, dan Brazil. Penyakit kronis seperti DM, jantung, dan kanker adalah masalah dunia yang jumlahnya terus meningkat, tidak terkecuali di Indonesia. Data terkini WHO memprediksikan jumlah penderita DM di Indonesia akan meningkat dari 8,4 juta tahun 2000 menjadi 21,3 juta di tahun 2030. Jumlah penderita DM ini, akan lebih besar dari jumlah seluruh penduduk Australia, sebagaimana diungkapan Gilbert Julien, Presiden Direktur Sanofi-
Aventis Indonesia di Jakarta (http://www. kabarbisnis.com, 20/11/2010)

Penelitian Goodridge dkk (2005) mengungkapkan DM dapat memengaruhi kualitas hidup para penderitanya terkait emosi negatif, efek sosial, berkurangnya aktivitas sosial, kondisi keluarga yang kurang kondusif seperti menjadi tegang atau perhatian berlebih, kerja yang sangat kurang (terhambat) hingga masalah keuangan. Grigg dkk (2006) mengungkapkan penderita DM mengalami penurunan kualitas hidup terkait dampak penyakit yang dialami.

Kondisi psikologis penderita DM juga erat kaitannya dengan aspek 
kognitif dan emosional dari strategi koping terhadap penyakit (illness-coping strategis), yang secara tidak langsung akan berpengaruh terhadap kebiasaan mencari obat. Penilaian atau kesadaran subjektif dari penderita DM bahwa dirinya mampu melakukan sikap hidup tersebut merupakan tanda pasien akan patuh terhadap pengobatan yang diberikan dan akan berpengaruh terhadap kualitas hidup penderita (Rose et al., 2002). Penelitian Solli dkk (2010) juga mengungkapkan bahwa penderita DM baik tipe 1 maupun tipe 2 mengalami penurunan kualitas hidup terkait ketakutan yang dialami atas komplikasi yang dapat ditimbulkan oleh penyakit tersebut.

Kualitas hidup merupakan hal-hal yang terdapat pada individu (Health Related Quality of Life/HRQOL) yang meliputi aspek fisik, psikologis, dan sosial, dari bidang kesehatan. Kualitas hidup adalah persepsi individu terkait dengan posisinya dalam hidup, baik dalam konteks budaya, sistem nilai yang berkembang menyangkut tujuan pengharapan standar, perhatian yang aspeknya meliputi fisik, psikologis, sosial, dari bidang kesehatan yang dipengaruhi oleh pengalaman pribadi seseorang, kepercayaan (spiritualitas) harapan serta persepsi (yang secara kolektif disebut dengan persepsi sehat) sehubungan dengan penyakit tertentu dan atau pengobatan.

Namun, Grigg dkk (2006) dalam penelitiannya juga mengungkapkan kualitas hidup penderita DM dapat ditingkatkan dengan mengatur pola makan, olahraga, dan mengkonsumsi obat secara teratur. Kualitas hidup pasien seharusnya menjadi perhatian penting bagi para profesional kesehatan karena dapat menjadi acuan keberhasilan dari suatu tindakan atau intervensi atau terapi. Di samping itu, data tentang kualitas hidup juga merupakan data awal untuk pertimbangan merumuskan intervensi/ tindakan yang tepat bagi pasien.

Penelitian ini menggunakan Rational Emotive Behavior Therapy (REBT) sebagai upaya peningkatan kualitas hidup penderita DM. REBT adalah humanisticexistential-constructivist, active-directive, filosofi dan empirik sebagai dasar psychotherapeutic dan psychological system of theory and practices yang dikembangkan oleh Albert Ellis (Corey, 1988). Eksistensial dalam terapi REBT memiliki pandangan bahwa manusia memiliki kebebasan dalam memilih, namun kebebasan tersebut bertanggung jawab. Hal tersebut memiliki arti bahwa manusia harus menerima segala resiko yang diakibatkan oleh pilihannya. Eksistensial humanistik, yang berfokus pada kondisi manusia, merupakan pendekatan yang mencakup terapiterapi yang berlainan yang semuanya berlandaskan konsep-konsep dan asumsiasumsi tentang manusia. Berikut ini adalah konsep-konsep utama dari pendekatan eksistensial yang membentuk landasan bagi praktek terapeutik, antara lain adalah 
(a) kesadaran diri, (b) kebebasan dan tanggung jawab, serta (c) penciptaan makna.

Terapi eksistensial bertujuan agar klien mengalami keberadaannya secara otentik dengan menjadi sadar atas keberadaan dan potensi-potensinya serta sadar bahwa ia dapat membuka diri dan bertindak berdasarkan kemampuannya. Terapi ini membantu meluaskan kesadaran diri klien, sehingga dapat membantu klien dalam kemampuan memilih pilihannya, menjadi bebas dan bertanggung jawab atas kehidupannya. Penerimaan tanggung jawab bukan suatu hal yang mudah, banyak orang yang takut menerima tanggung jawab atas pilihannya. Hal tersebut dapat terjadi karena tidak adanya jaminan-jaminan dalam pilihannya itulah yang dapat menimbulkan kecemasan. Terapi eksistensial membantu klien agar mampu menghadapi kecemasan sehubungan dengan tindakan memilih diri dan menerima kenyataan. Bugental (Corey, 1988) menyebutkan tiga karakteristik keberadaan otentik, yaitu (a) menyadari sepenuhnya keadaan sekarang, (b) memilih bagaimana hidup pada saat sekarang, dan (c) memikul tanggung jawab untuk memilih.

Active directive dalam terapi initerapis secara aktif membantu membimbing dan melatih klien dalam menyelesaikan masalah, namun keputusan ada pada klien yang bersangkutan. Terapi membantu klien untuk menyadari keadaan saat ini, membantu klien agar mampu mengatasi kecemasan yang terkait dengan tindakan memilih dan menerima kenyataan. REBT adalah cognitive-behavioral and psychoeducational therapeutic system dan dengan pendekatan yang komprehensif untuk meningkatkan keberfungsian individu yang dapat diaplikasikan baik klinis maupun bidang lainnya. Terapi ini menggunakan metode kognitif perilaku, dengan menyisipkan psiko-edukasi dalam pelaksanaan proses terapinya. Terapi REBT adalah terapi konseling yang digunakan untuk memanaje masalah maladaptif dengan memfokuskan pada keyakinan irasional yang memunculkan emosi negatif, dan dengan terapi ini akan digantikan dengan hal yang rasional dan produktif sebagai harapan akan mengubah kebiasaan individu (Egbochuku, 2007) .

REBT telah dipraktikan sendiri oleh Ellis, baik pada dirinya sendiri maupun kliennya yang mengalami DM (Ellis, 1997). Ellis mengungkapkan bahwa REBT dapat membantu hidup bersahabat seorang penderita DM sejak usia 40 tahun. REBT juga dapat digunakan oleh klienklien yang memiliki keterbatasan lain atau cacat fisik. Ellis ingin menunjukkan bahwa dirinya tidak hanya merancang beberapa filosofi yang masuk akal untuk orang cacat, namun dirinya benarbenar menerapkan dalam pekerjaan dan kehidupan pribadinya sendiri.

Menurut Perkeni (Shahab, 2006), DM adalah suatu penyakit di mana kadar glukosa (gula sederhana) di 
dalam darah tergolong tinggi karena tubuh tidak dapat melepaskan atau menggunakan insulin secara cukup. Insulin adalah hormon yang dilepaskan oleh pankreas, yang bertanggung jawab dalam mempertahankan kadar gula darah yang normal. Insulin memasukkan gula ke dalam sel sehingga bisa menghasilkan energi atau disimpan sebagai cadangan energi. Jika sudah mengidap penyakit ini penderita secara fisik dan psikis merasa terganggu. Umumnya penyakit diabetes memberi dampak komplikasi yang cukup mengkhawatirkan, seperti kelumpuhan, luka yang sulit disembuhkan, bahkan penyakit pengikut. Untuk mengatasi diabetes, perlu penanganan khusus, yaitu metode terapi kedokteran yang komprehensif. Selain pengobatan medis, pasien juga diterapi secara psikologis berupa pendidikan tentang diabetes.

REBT adalah terapi konseling yang digunakan untuk memanaje masalah maladaptif dengan memfokuskan pada keyakinan irasional yang memunculkan emosi negatif, dan melalui terapi ini akan digantikan dengan hal yang rasional dan produktif sebagai harapan akan mengubah kebiasaan individu (Egbochuku, 2008). Esensi REBT adalah untuk menggali (menentukan dan mengidentifikasi) maladaptif dan merusak pikiran-perasaanperilaku dan kemudian untuk memulai pertanyaan, tantangan, perselisihan dengan mengetahui keyakinan irasional mereka dan secara aktif dan tegas membantu mengubah menjadi rasional. Keberfungsian pikiran-perasaan-perilaku adalah inti dari kesehatan mental.

Pada REBT terdapat proses belajar untuk menyelesaikan suatu masalah tertentu. Namun hal-hal yang sudah dipelajari prosesnya dapat digunakan dalam menyelesaikan masalah lain yang relevan. Dalam terapi ini klien belajar untuk berfikir rasional dan meninggalkan keyakinan (pikiran) yang irasional kemudian menggantinya dengan keyakinan (pikiran) yang rasional. Keyakinan irasional tersebut akan merusak diri klien karena dapat menimbulkan emosi negatif dan perilaku maladaptif. Terapis bertugas membantu klien untuk menjalani proses tersebut (Dryden \& Neenan, 2003b; Ellis, 2003).

Subjek penelitian ini diharapkan dapat merasa lebih senang, rileks, tidak merasa kecewa, dan marah. Terkait dengan tingkah laku yang adaptif, individu dapat melakukan self monitoring diabetes mellitus yang dideritanya. Dengan adanya hal tersebut diharapkan kualitas hidup penderita diabetes mellitus dapat meningkat.

Berdasarkan pada uraian yang telah dikemukakan di atas, maka hipotesis dalam penelitian ini dirumuskan sebagai berikut: Ada peningkatan kualitas hidup penderita diabetes mellitus antara sebelum dan sesudah mengikuti pelatihan rational emotive behavior therapy. 


\section{METODE PENELITIAN}

\section{Subjek Penelitian}

Subjek penelitian yang digunakan dalam penelitian ini adalah pasien rawat jalan yang menderita diabetes mellitus di Puskesmas Ngaglik I Sleman. Metode pengambilan subjek penelitian adalah purposive sampling, yaitu pemilihan subjek penelitian yang memiliki kriteria tertentu. Kriteria subjek yang digunakan untuk mencapai tujuan penelitian serta menjaga validitas isi dalam penelitian ini adalah sebagai berikut:

1. Jenis kelamin laki-laki dan perempuan

2. Usia di bawah 60 tahun, dengan alasan skor kualitas hidup menurun murni karena diabetes yang diderita bukan karena penurunan kualitas hidup karena usia.

3. Memiliki skor kualitas hidup rendah atau sedang.

4. Belum pernah mengikuti kegiatan atau pelatihan baik kognitif, relaksasi, dengan alasan dapat memengaruhi hasil dari terapi yang akan dikenakan terhadap subjek, bukan karena pengalaman yang telah dimiliki sebelumnya.

Subjek yang digunakan dalam penelitian ini berjumlah 21 orang yang kemudian dibagi menjadi kelompok eksperimen dan kelompok kontrol kemudian dilakukan matching subject dengan penyetaraan pendidikan. Kemudian diperoleh 12 orang kelompok eksperimen dan 9 orang kelompok kontrol sebagai kelompok waiting list. Namun selanjutnya terdapat drop out untuk kelompok eksperimen sebanyak 5 orang hingga akhir penelitian kelompok eksperimen menjadi 7 orang.

\section{Rancangan Penelitian}

Penelitian ini adalah penelitian kuasi eksperimen. Stouffer dan Campbell (Dicky, 2008) merumuskan eksperimen kursi sebagai eksperimen yang memiliki perlakuan, pengukuran dampak, unit eksperimen, namun tidak menggunakan penugasan acak untuk menciptakan pembandingan dalam rangka menyimpulkan perubahan yang disebabkan perlakuan. Perhatian utama penelitian hanya pada efek perlakuan. Tipe eksperimen kursi rancangan kelompok tak setara (nonequivalent group designs), biasanya perilaku kelompok eksperimen dan kelompok kontrol diukur sebelum dan sesudah perlakuan.

Rancangan eksperimen untuk penelitian ini adalah pretest-posttest control group design (Kazdin, 1995). Adapun bentuk rancangan tersebut dapat dilihat pada gambar berikut ini.

\begin{tabular}{|cccc|}
\hline KE & $Y 1$ & $X$ & $Y 2$ \\
KK & $Y$ & - & $Y 2$ \\
KK & $Y 1$ & $\sim X$ & $Y 3$ \\
\hline
\end{tabular}

Gambar 3. Rancangan Eksperimen

\section{Keterangan :}

KE : Kelompok Eksperimen

KK : Kelompok Kontrol 
Y1 : Prates

$\mathrm{X} \quad$ :Rational Emotive Behavior Therapy

$\sim \mathrm{X}$ : Waiting list

Y2 : Pascates, Evaluasi, Follow up

Y3 : Pascates, kemudian diberikan

Psikoedukasi terkait diabetes

mellitus

Y1 selain digunakan sebagai prates juga di gunakan sebagai alat screening, terhadap subjek yang akan dimasukkan dalam penelitian ini.

\section{Pengukuran}

Pengumpulan data dalam penelitian ini diperoleh melalui kuesioner yang berbentuk skala yang merupakan hasil modifikasi dari Diabetes Quality of Life Clinical Trial Questioner-Revised (DQOLCTQ-R) sebagai alat ukur. Versi revisi terdiri dari 57 aitem, dan 7 domain yaitu: (1) Fungsi fisik (physical function), (2) Energi (energy/fatigue), (3) Kesehatan (health distress), (4) Kesehatan mental (mental health), (5) Kepuasan pribadi (satisfaction), (6) Kepuasan pengobatan (treatment flexibility), (7) Gejala gejala penyakit (frequency of symtoms). Skor yang lebih tinggi menandakan suatu status kesehatan yang lebih baik (Shen et al., 1999).

Kuesioner DQOLCQ-R memiliki validitas dan reliabilitas baik, jarak $\alpha$ Cronbach dari 0,77 sampai 0,90 dan jarak hubungan interklas adalah 0,74 sampai 0,99 dengan pengecualian yang hampir tidak ada (Shen dkk, dalam Wildes dkk.,
2003). Validitas dan reliabilitas ini sudah pernah diuji melalui uji kelayakan yang dilakukan terhadap 35 penderita DM tipe 2 di Rumah Sakit DR. Sardjito Yogyakarta pada bulan Januari hingga Maret 2002, yaitu dengan melihat distribusi respon, korelasi antar aitem, korelasi aitem total, dan konsistensi internal serta menentukan status aitem. Pada analisis aitem menyeluruh dari hasil uji kelayakan nilai konsistensi internal alpha seluruh aitem $>0,5(0,82)$ (Hartini, 2003).

\section{Prosedur Intervensi}

Pelaksanan terapi dalam penelitian ini meliputi tiga tahapan. Antara lain sebagai berikut :

1. Terapi yang dilakukan pada saat prates hingga sebelum terapi di puskesmas yang dilakukan sebanyak tiga kali pertemuan pada masing masing peserta. Peneliti melakukan terapi kognitif dan psikoedukasi sebagai bagaian teknik REBT. Selain untuk menjalin rapport juga dapat memperoleh data yang dalam serta dapat mengenalkan dan membiasakan peserta berfikir lebih rasional.

2. Terapi yang dilakukan di puskesmas. Terapi untuk sesi I, II, III dilaksanakan dalam satu kali pertemuan. Pada pertemuan pertama subjek diberikan tugas, dan tugas tersebut dijadikan bahan untuk sesi II, III, dan sesi IV. Pemberian tugas tersebut sebagai upaya meringankan beban subjek 
terhadap tugas. Kemudian untuk pelaksanan sesi II kognitif dan sesi III emotif dilaksanakan satu kali pertemuan. Hal tersebut karena dalam terapi REBT, sesi kognitif dan emotif sangat erat sekali kaitannya. Sesi kognitif dan emotif dilaksanakan dalam satu kali pertemuan diharapkan akan mempermudah subjek untuk mencerna, internalisasi tentang apa yang disampaikan terapis dan dapat mempraktikannya. Namun apabila dua sesi dilaksanakan terpisah dikhawatirkan subjek akan kesulitan mencerna, mengingat apa yang disampaikan terapis, sehingga subjek akan mengalami kesulitan dalam mempraktikannya. Sesi IV, yaitu behavior dilaksanakan selang satu hari setelah pertemuan pertama.

3. Terapi yang dilakukan pada saat monitoring diabetes. Peneliti berkunjung di kediaman peserta sebanyak enam kali dalam jangka waktu 30 hari. Dalam penelitian ini karena keterbatasan peneliti, monitoring terhadap subjek penelitian hanya dilakukan setiap 4 hari sekali. Terapi yang digunakan saat home visit adalah terapi kognitif dan psikoedukasi. Selain itu adanya observer dari pihak keluarga subjek juga mengalami hambatan, karena tidak semua observer dapat mengawasi subjek dengan maksimal. Peneliti juga menjelaskan ulang terkait pencatatan observasi peserta pada observer. Support therapy dalam pelaksanaan terapi ini lebih ke arah pemberian terapi kognitif, psikoedukasi, dan memberikan contoh nyata, fakta yang ada terkait akibat tindakan maladaptif yang dilakukan peserta atau penderita diabetes lain, baik yang baik maupun yang buruk. Hal tersebut dilakukan dengan harapan agar dapat meningkatkan motivasi peserta unuk terus melakukan tugastugas secara berkesinambungan. Selain itu juga diharapkan peserta dapat memahami jika semua yang dilakukan demi kesehatan dan diri peserta sendiri. Agar peserta dapat menjadi terapis bagi dirinya sendiri dan tidak tergantung pada orang lain dapat berteman dengan diabetes mellitus dan memiliki kualitas hidup yang lebih baik.

Viens dan Hranchuck (Mc Leond, 2006) mengungkapkan bahwa monitoring terhadap pasien yang diterapi setiap minggu memiliki kontribusi yang sangat besar untuk menguatkan kemajuan dan perkembangan klien, jauh dibanding kontribusi terapis saat sesi terapi berlangsung. Hal ini menunjukkan bahwa proses monitoring peserta terapi sangat penting.

Ellis (1997) juga mengungkapkan hal yang sama. Pada saat kondisi kesehatan Ellis memburuk hingga harus dirawat di rumah sakit, Ellis memutuskan untuk 
memiliki dokter dan perawat untuk membantu dan memonitor kebiasaan baru yang harus dilakukannya tersebut. Ellis juga mengemukakan jika hal tersebut sangat membantunya membut kondisinya stabil.

Tahap prates dilaksanakan mulai 11 April 2011 hingga 10 Juni 2011 di kediaman penderita diabetes. Alasan peneliti memilih melakukan prates dengan home visit karena pengambilan data pada tahap prates bertujuan yaitu:

1. Untuk kategorisasi adalah membuat kategorisasi tingkat kualitas hidup penderita diabetes mellitus sesuai dengan norma masing - masing kelompok kategori.

2. Untuk seleksi subjek penelitian, yaitu menyeleksi dan mengelompokkan subjek penelitian yang termasuk dalam ketegori kualitas hidup rendah dan sedang untuk diikutsertakan dalam keseluruhan proses penelitian, yang dilakukan peneliti secara sukarela. Bagi subjek yang memiliki kualitas hidup rendah dan sedang selanjutnya akan dihubungi peneliti berkaitan dengan kesediaan subjek penelitian untuk mengiukuti keseluruhan proses secara sukarela

3. Aitem yang terdapat dalam skala kualitas hidup digunakan oleh peneliti sebagai guide interview, sehingga proses interview tidak melebar dan dapat inquiry setiap subjek dan mendapatkan data-data penelitian lebih detail. Peneliti dapat mengetahui masalah yang dialami subjek pada saat prates.

5. Pada saat prates ini juga digunakan sebagai tahap bulding rapport peneliti terhadap peserta terapi dan keluarga peserta. Dengan harapan selain mendapatkan data skala kualitas hidup peserta, peneliti juga dapat melakukan deep interview lebih mudah.

6. Selain itu juga mendapatkan informasi terkait penelitian ini dari keluarga peserta.

Pada saat prates peneliti juga melakukan psikoedukasi serta support pada penderita diabetes. Pelaksanaan proses terapi ini di aula Puskesmas Ngaglik I Sleman pada tanggal 20, 22 Juni 2011 serta tanggal 25 Juli 2011. Pada tanggal 23 Juni hingga tanggal 24 Juli para peserta malakukan penerapan metode yang telah diajarkan dan dipelajari secara bersama terapis di rumah masing-masing. Setiap 4 hari sekali peneliti melakukan monitoring di rumah masing masing peserta.

Sebelum pelaksanaan terapi peneliti berkunjung sebanyak tiga kali pada masing-masing peserta terapi (kelompok eksperimen). Kunjungan pertama bertujuan untuk pengisian skala kualitas hidup, bulding rapport pada peserta dan keluarga, penjelasan maksud dan tujuan pengisian skala, dan penjelasan terkait terapi yang akan dilaksanakan, selain itu peneliti juga melakukan 
interview. Kunjungan kedua bertujuan untuk persetujuan inform consent serta penjelasan singkat mengenai pelaksanaan terapi. Peneliti juga melakukan kognitif terapi, psikoedukasi terhadap peserta, peneliti juga melakukan bulding rapport pada peserta dan keluarga peserta yang akan menjadi observer selama peserta melakukan tugas mendiri di rumah. Pada kesempatan ini peneliti juga menyerahkan informed consent pada observer. Kunjungan ketiga bertujuan untuk menyerahkan undangan terapi pada peserta terapi.

Terkait dengan pemberian terapi kognitif, psikoedukasi yang diberikan pada peserta saat prates hingga sebelum peleksanaan terapi adalah dengan menggunakan apa yang ada dalam pikiran peserta yang dapat memunculkan keyakinan irasional, kemudian membantahnya dengan fakta. Informasi tersebut diperoleh pada waktu pengisian skala kualitas hidup.

Proses terapi tidak hanya dilakukan di puskesmas saja namun juga dilakukan di rumah peserta terapi. Terapi yang digunakan sesuai dengan kebutuhan masing-masing peserta. Proses terapi dan support terapi dilakukan 4 hari selama satu bulan selama proses monitoring berlangsung. Peneliti juga mengambil data observasi dari anggota keluarga peserta terapi. Selain memberikan support dan terapi pada peserta, peneliti juga memberikan support serta psikoedukasi pada keluarga peserta terapi. Setelah monitoring berlangsung selama satu bulan penuh diadakan pascates.

\section{Teknik Analisis Data}

Analisis yang digunakan dalam penelitian ini adalah statistic non parametric program Uji Mann-Whitney (Uji U). Hal ini mengingat ukuran sampel yang digunakan dalam penelitian ini adalah berukuran kecil, yaitu masing masing kelompok terdiri dari 7 orang.

Analisis kuantitatif juga dilakukan dalam penelitian ini, yaitu untuk mengetahui keadaan subjek melalui catatan harian dapat menggambarkan keadaan subjek selama proses penelitian berlangsung.

\section{HASIL PENELITIAN}

\section{Deskripsi Data}

Diskripsi data penelitian yang berupa rerata empirik diperoleh dari hasil prates dan pascates skala kualitas hidup diabetes mellitus dapat dilihat pada tabel berikut ini: 
Tabel 4. Distribusi Rerata Skor Kualitas Hidup (Prates dan Pascates)

\begin{tabular}{lcccc}
\hline \multirow{2}{*}{ Skor } & \multicolumn{2}{c}{ Kelompok Eksperimen } & \multicolumn{2}{c}{ Kelompok Kontrol } \\
\cline { 2 - 5 } & Rerata Empirik & Kategori & Rerata Empirik & Kategori \\
\hline Prates & 458,68 & Rendah & 475,27 & Sedang \\
Pascates & 521,15 & Sedang & 479,75 & Sedang \\
\hline
\end{tabular}

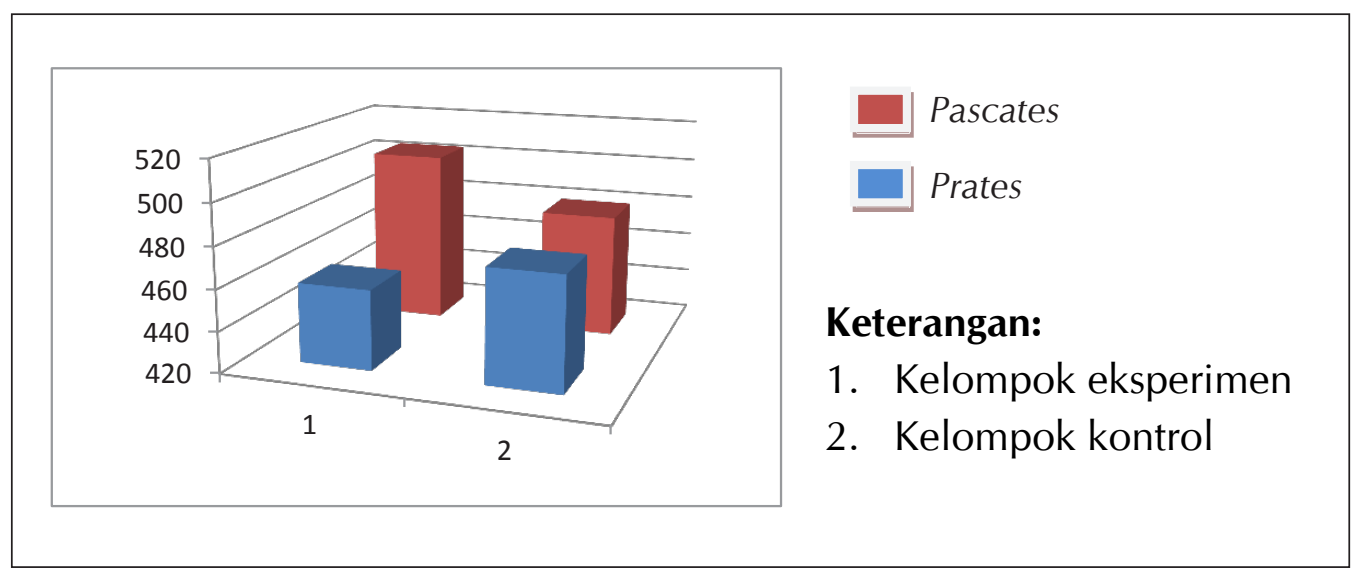

Gambar 5. Rerata Skor Kualitas Hidup Diabetes Mellitus Kelompok Eksperimen dan Kelompok Kontrol

Melalui diskipsi data penelitian dengan perubahan peningkatan kategori yang telah terangkum pada tabel di atas, selanjutnya dapat dibuatkan histogram rerata skor kualitas hidup diabetes mellitus pada kelompok eksperimen maupun kelompok kontrol yang tersaji dalam gambar 5 .

Mencermati histogram rerata skor pada kualitas hidup diabetes mellitus dapat disimpulkan bahwa pada saat pascates terjadi peningkatan skor kualitas hidup diabetes mellitus. Hampir semua kualitas hidup diabetes mellitus pada subjek yang bersangkutan. Hanya ada dua orang subjek yang mengalami peningkatan skor kualitas hidup namun tidak diikuti dengan perubahan peningkatan kategori kualitas hidup. Dalam data penelitian secara kelompok berikut disajikan pula data penelitian dari tiap subjek pada kelompok eksperimen maupun kelompok kontrol secara lebih rinci pada tabel berikut: peningkatan skor kualitas hidup diikuti 
Tabel 5. Skor Prates dan Pascates Kualitas Hidup Tiap Subjek Kelompok Eksperimen dan Kontrol

\begin{tabular}{lccccc}
\hline Kelompok & Subjek & Skor Prates & Kategori & Skor Pascates & Kategori \\
\hline Eksperimen & 1 & 400,33 & Rendah & 504,98 & Sedang \\
& 2 & 406,27 & Rendah & 421,6 & Rendah \\
& 3 & 450,8 & Rendah & 474,63 & Sedang \\
& 4 & 462,33 & Rendah & 496,56 & Sedang \\
& 5 & 495,05 & Sedang & 528,71 & Sedang \\
& 6 & 497,05 & Sedang & 545,88 & Tinggi \\
& 7 & 498,9 & Sedang & 556,92 & Tinggi \\
\hline Kontrol & 1 & 447,58 & Rendah & 447,58 & Rendah \\
& 2 & 389,52 & Sanggat Rendah & 404,45 & Rendah \\
& 3 & 427,49 & Rendah & 446,93 & Rendah \\
& 4 & 490,05 & Sedang & 490,05 & Sedang \\
& 5 & 493,04 & Sedang & 493,04 & Sedang \\
& 6 & 522,98 & Sedang & 522,98 & Sedang \\
& 7 & 530,2 & Sedang & 530,2 & Sedang \\
\hline
\end{tabular}

\section{Hasil Uji Hipotesis}

Analisis data uji non parametrik Mann-Whitney (U-test) menghasilkan data sebagai berikut:

Tabel. 6. Analisis Mann- Whitney (Uji U) Kualitas Hidup

\begin{tabular}{lccccccc}
\hline & & \multicolumn{2}{c}{ Prates } & \multicolumn{2}{c}{ Pascates } & \multicolumn{2}{c}{ Gain Score } \\
\cline { 3 - 8 } Kelompok & N & $\begin{array}{c}\text { Mean } \\
\text { Rank }\end{array}$ & $\begin{array}{c}\text { Sum of } \\
\text { Rank }\end{array}$ & $\begin{array}{c}\text { Mean } \\
\text { Rank }\end{array}$ & $\begin{array}{c}\text { Sum of } \\
\text { Rank }\end{array}$ & $\begin{array}{c}\text { Mean } \\
\text { Rank }\end{array}$ & $\begin{array}{c}\text { Sum of } \\
\text { Rank }\end{array}$ \\
\hline Eksperimen & 7 & 7,29 & 51,00 & 8,57 & 60,00 & 10,86 & 76,00 \\
Kontrol & 7 & 7,71 & 54,00 & 6,43 & 45,00 & 4,14 & 29,00 \\
\hline
\end{tabular}


Tabel 7. Analisis Mann-Whitney (Uji U) Skor Kualitas Hidup

\begin{tabular}{lcccc}
\hline \multicolumn{1}{c}{ Skor } & Mann-Whitney $\boldsymbol{U}$ & Wilcoxon $\boldsymbol{W}$ & $\boldsymbol{Z}$ & Asymp. \\
\hline Prates & 23,000 & 51,000 &,- 192 & 0,848 \\
Pascates & 17,000 & 45,000 &,- 958 & 0,338 \\
Gain & 1,000 & 29,000 & $-3,071$ & 0,002 \\
\hline
\end{tabular}

Tabel 8. Distribusi Hasil Mann- Whithney (Uji U) Gain Score Kualitas Hidup

\begin{tabular}{cc}
\hline Analisis & Gain score subjek penelitian \\
\hline Mann-Whitney U & 1,000 \\
Wilcoxon W & 29,000 \\
Z & $-3,071$ \\
Asymp. Sig. (2-tailed) &, 002 \\
Exact Sig. [2*(1-tailed Sig.)] &, $001(\mathrm{a})$ \\
\hline
\end{tabular}

Berdasarkan hasil analisis uji MannWithney di atas, dapat diketahui bahwa ada perbedaan yang signifikan antara kualitas hidup penderita diabetes mellitus saat sebelum diberikan intervensi dan setelah mendapatkan intervensi berupa rational emotive behavior therapy. Hal ini ditunjukkan dengan hasil $z=-3,071$ dengan $p=0,002(p<0,05)$. Dengan demikian dapat disimpulkan bahwa ada perbedaan yang signifikan antara skor kualitas hidup kelompok eksperimen dan skor kualitas hidup kelompok kontrol pada subjek penelitian.

\section{PEMBAHASAN}

Hasil penelitian menunjukkan masing-masing peserta mengalami perubahan skor yang berbeda satu dengan yang lainnya. Subjek pertama mengalami peningkatan skor yang cukup tinggi dan taraf kualitas hidup. Hal ini sangat dimungkinkan karena subjek melakukan terapi di rumah secara teratur, baik dalam pola makan, olahraga, relaksasi maupun terapi kognitif. Terapi kognitif yang dilakukan subjek masih membutuhkan bimbingan dari peneliti dan support. Selain itu istri sangat mendukung subjek.

Subjek kedua mengalami kenaikan poin, namun tidak mengalami peningkatan kualitas hidup. Hal ini mungkin disebabkan subjek tidak teratur pola makannya, yaitu masih banyak mengkonsumsi makanan yang semestinya dihindari. Subjek juga tidak melakukan olahraga secara teratur. Oleh karena itu, walaupun subjek secara kontinyu mengkonsumsi insulin dan relaksasi sehari tiga kali, namun terapi ini belum 
dapat memperbaiki kualitas hidup subjek. Hal lain yang juga terjadi adalah support yang diberikan oleh keluarga juga kurang. Secara umum dapat dikatakan bahwa proses terapi tidak dilakukan seluruhnya, misalnya subjek tidak melakukan terapi perilaku (behavior therapy).

Subjek ketiga mengalami kenaikan skor dan taraf kualitas hidup. Hal ini dimungkinkan karena subjek setiap hari melakukan relaksasi, olahraga, serta mengatur pola makan. Support dari keluarga juga sangat bagus.

Subjek keempat juga mengalami kenaikan skor dan taraf kualitas hidup. Subjek mengatur pola makan serta berolahraga. Support dari keluarga sangat besar terutama dalam membantu subjek untuk mengatur jadwal dan pola makan.

Subjek kelima mengalami kenaikan skor namun tidak signifikan. Kualitas hidup subjek tidak berubah. Subjek menjalankan pola makan diabetes, namun masih suka melanggar dan ketika merasa tidak nyaman akan mengkonsumsi obat. Subjek melakukan relaksasi teratur setiap hari serta berolahraga. Namun pada saat proses terapi subjek dua kali menderita sakit. Subjek mendapatkan support yang cukup baik dari keluarga.

Subjek keenam mengalami kenaikan skor dan taraf kualitas hidup secara signifikan. Subjek rajin sekali melakukan relaksasi di rumah. Selain itu juga menjaga pola makan. Olahraga juga dilakukan subjek. Peneliti sering memberikan psikoedukasi terkait pola makan dan jenis makanan kepada subjek.

Subjek ketujuh mengalami kenaikan skor dan taraf kualitas hidup. Subjek rajin sekali melakukan relaksasi, mengaku sangat nyaman ketika melakukannya dan dapat mengobati insomnia yang dialaminya selama ini. Subjek juga sangat menjaga pola makannya, selain rutin olahraga. Namun subjek tidak mengkonsumsi obat dokter dan hanya mengandalkan pengobatan herbal. Support yang diberikan pada teman teman dan keluarga sangat besar. Peneliti sering melakukan psikoedukasi dan terapi kognitif pada subjek terkait rasa rendah dirinya karena mengalami diabetes di usianya yang masih muda.

Berdasarkan hasil penelitian yang telah diuraikan secara rinci di atas, hipotesis diterima untuk subjek penelitian dan belum dapat digeneralisasikan pada subjek yang lebih luas. Diterimanya hipotesis dapat dijelaskan dengan memperhatikan aspek-aspek berikut yang dapat memberi pengaruh terhadap terjadinya diterimanya hipotesis.

Subjek penelitian telah menunjukkan kedisiplinan dalam melakukan diet diabetes, olahraga, relaksasi, maupun munculnya pikiran negatif. Melalui catatan harian subjek diperoleh data kualitatif dalam rentang proses eksperimen berlangsung selama 4 minggu berturutturut. Berdasarkan data yang diperoleh, diketahui 2 orang subjek dalam kelompok 
eksperimen tidak teratur dalam melakukan diet, relaksasi, dan olahraga. Data tersebut juga menunjukkan adanya 2 orang subjek yang tidak mengkonsumsi obat dokter, dalam hal ini, ada beberapa subjek yang tidak sepenuhnya menjalankan tugastugas yang diberikan oleh terapis.

Mencermati deskripsi kegiatan tiap subjek, dalam rentang 4 minggu berturutturut, subjek yang mengalami peningkatan kualitas hidup adalah subjek yang melakukan diet diabetes sehingga kalori yang masuk sesuai dengan kebutuhan. Selain itu juga melakukan kontrol glukosa darah secara teratur, minum obat sesuai anjuran dokter, juga melakukan relaksasi, telah dapat mengambil hikmah, menerima kondisi dengan `diabetes yang dimilikinya, sehingga pikiran negatif dan rasa takut sudah sangat berkurang bahkan tidak ada dan menimbulkan tingkah laku positif atau yang mendukung untuk kestabilan kondisi baik fisik maupun psikis. Selain itu subjek juga melakukan olahraga secara teratur.

Terapi ini mengajarkan bagaimana peserta dapat berfikir positif atau mengambil hikmah, sehingga dapat membantu memunculkan rasa lebih nyaman dan dapat menerima kondisi dirinya. Terapi REBT ini hampir 90\% sesi digunakan untuk mengubah cara berfikir peserta agar menjadi rasional sehingga dapat membuang keyakinan irasional yang dimilikinya dan melatih peserta agar mengetahui apa yang sebaiknya dilakukan dalam menyikapi, menghadapi maupun menyelesaikan suatu masalah (Spiegler, 2010). Selain itu juga melatih peserta relaksasi agar dapat memaksimalkan rasa nyaman, tenang, dan dapat mengurangi kecemasan yang dialami. Hasil penelitian ini menunjukkan bahwa terapi REBT ini berpengaruh pada meningkatnya kondisi kesehatan mental dan aspek energi yang menjadi lebih positif pada peserta. Kecemasan pada peserta mengalami penurunan bukan karena unsur obat yang dikonsumsi. Karena menurut penuturan dokter puskesmas terkait, obat yang diberikan pihak puskesmas semuanya tidak ada yang memiliki efek menurunkan kecemasan. Adapun obat yang dikonsumsi oleh peserta antara lain:

1. Suntik insulin yang (insulin glargine, ultralente insulin) yang menstimulasi sekresi insulin alami.

2. Metformine merupakan obat yang cara kerjanya terutama menurunkan glukosa darah dengan menekan produksi glukosa yang diproduksi hati dan mengurangi resistensi insulin.

3. Glibenclamid menstimulasi selsel beta dalam pankreas untuk memproduksi lebih banyak insulin. Obat ini juga membantu sel-sel dalam tubuh menjadi lebih baik dalam mengelola insulin

Selain itu REBT juga melatih peserta agar dapat menjalankan diet diabetes untuk menjaga pola makan yang sesuai dengan 
kebutuhan. Apabila peserta menjalankan dengan baik sesuai anjuran, maka kualitas hidup akan lebih baik. Temuan di atas sejalan dengan pendapat Perkin (Shahab, 2006). Menurutnya, penderita diabetes harus menjalankan empat pilar monitoring diabetes yang terdiri atas pengontrolan pola makan, konsumsi obat sesuai anjuran, pengontrolan kadar gula darah, dan olahraga secara teratur minimal 3 atau 4 kali seminggu dengan durasi minimal 30 menit. Selain itu karena penderita diabetes mellitus mengalami kecemasan atau gangguan ketidakstabilan emosi, maka mereka dianjurkan untuk melakukan relaksasi. Meditasi relaksasi membantu penyembuhan penderita Miabetes Mellitus Tidak Tergantung Insulin (DMTTI). Demikian hasil penelitian yang diungkapkan April 1999 oleh tim peneliti Universitas Udayana. Menurut Suryani (2000), dalam melaksanakan meditasi relaksasi spirit diperlukan ketekunan dan kedisipinan untuk memperoleh perubahan dalam kehidupan sehari hari. Hasil penelitian yang dilakukan Suryani dan tim penelitian lainnya juga menemukan bahwa penderita diabetes millitus tipe 2 yang melakukan meditasi relaksasi spirit secara teratur menunjukkkan tingkat kesembuhan atau kesehatan yang baik dan berpengaruh pada pola tidur yang baik pula, apabila dibandingkan dengan penderita diabetes mellitus tipe 2 yang melakukan meditasi relaksasi spirit secara tidak teratur dan penderita diabetes mellitus tipe 2 yang tidak melakukan meditasi relaksasi spirit (Kompas, 2008/11/13).

Namun bila individu didiagnosis menderita diabetes mellitus tentunya akan timbul reaksi dalam diri individu tersebut secara psikologis, seperti pengingkaran, marah, perasaan bersalah, depresi, maupun penerimaan diri yang rendah. Hal ini dapat terjadi karena kondisi penderita diabetes mellitus tidak dapat diperbaiki menjadi keadaan normal seperti sebelum individu didiagnosis menderita diabetes mellitus, kondisi yang tidak menyenangkan dan tidak diharapkan, serta indivdu membutuhkan waktu kurang lebih 12 bulan untuk dapat menerima penyakit diabetes mellitus yang diderita tersebut (Sridhar \& Madhu, 2001; Sridhar \& Madhu, 2002). Secara psikologis biasanya penderita diabetes mellitus mengalami stres secara emosional, munculnya perasaan-perasaan negatif termasuk perasaan putus asa, tidak berdaya, cemas dan depresi (McCranty, Atkinson \& Lipsenthal, 2000).

Selain reaksi pengingkaran, marah, perasaan bersalah, depresi, maupun rendahnya penerimaan diri yang mungkin terjadi pada diri individu ketika didiagnosis menderita diabetes mellitus, muncul pula reaksi psikologis lainnya seperti shock, ecounter dan retreat. Shock adalah reaksi psikologis dengan karakteristik seolaholah akan pingsan atau merasa bingung, adanya reaksi otomatis yang ditunjukkan, adanya perasaan ingin melepaskan diri 
dari situasi yang terjadi. Encounter adalah reaksi yang muncul sebagai refleksi dari adanya ketidakselarasan antara pikiran dan adanya perasaaan kehilangan, tidak berdaya, sedih, putus asa, merasa kewalahan terhadap kenyataan yang terjadi. Retreat merupakan reaksi psikologis yang ditunjukkan dengan adanya strategi pengalihan yang cenderung digunakan oleh individu yang didiagnosis penyakit kronis (Sarafino, 1997; Taylor \& Stanton, 2007).

Kondisi ini dapat terjadi mengingat bahwa diabetes mellitus adalah salah satu penyakit kronis yang memerlukan perubahan baik jangka pendek maupun jangka panjang. Perubahan menyangkut berbagai aspek kehidupan individu yang didiagnosis secara fisik, aktivitas rutin sehari-hari maupun kehidupan sosial. Penyakit diabetes mellitus ini juga terkait dengan gaya hidup hingga berdampak pada aspek - aspek kehidupan individu penderita diabetes mellitus. Dampak dari penyakit diabetes mellitus terhadap aspek - aspek kehidupan membutuhkan suatu pengelolaan secara kompleks dan menuntut individu penderita diabetes mellitus dapat melaksanakan program perubahan perilaku secara tepat dan disiplin. Pengintegrasian kondisi psikologis pada diri penderita penyakit kronis, dalam hal ini diabetes mellitus, memiliki peran penting dalam proses adaptasi terhadap penyakit yang diderita (Sridhar \& Madhu, 2001; Sridhar \& Madhu, 2002; Taylor \& Stanton, 2007).
Sebaliknya, subjek yang tidak menaati diet diabetes, tidak melakukan olahraga, walaupun subjek tersebut sudah menerima kondisinya, mengkonsumsi obat dokter berupa suntik insulin sesuai anjuran dokter dan secara berkala kontrol gula darah serta melakukan relaksasi sesuai anjuran, tetap memiliki kualitas hidup yang rendah. Hal ini seperti yang terjadi pada subjek penelitian yang bernama Myt. Hal tersebut dapat terjadi karena jumlah kalori yang masuk tidak sesuai dengan kebutuhan tubuh (Shahab, 2002). Pembakaran kalori yang tidak maksimal karena subjek tidak melakukan aktivitas misalnya olahraga menyebabkan kadar gula dalam darah tetap tinggi (Sukardji, 2008). Oleh karena ketidakdisiplinan subjek penelitian dalam melakukan diet, olahraga berpengaruh terhadap perubahan maupun manfaat yang dapat diperoleh dari tugas tugas tersebut.

Tingkat motivasi subjek penelitian dalam melakukan tugas - tugas juga dapat memengaruhi hasil yang akan diperoleh. Hal ini tampak dalam observasi dari key person subjek saat menjalankan tugastugas selama proses terapi berlangsung. Apabila subjek melakukan tugas-tugasnya dengan baik, maka dampaknya terasa bagi subjek, yang otomatis bertambah pula skor kualitas hidup subjek tersebut. Hackney dan Cormier (Gibson \& Mitchell, 2011) mengungkapkan individu yang memiliki motivasi yang besar akan mendapatkan efek terapi yang baik dibandingkan 
individu yang memiliki motivasi rendah, karena individu yang memiliki motivasi yang tinggi memiliki orientasi tujuan yang kuat. Individu yang memiliki orientasi tujuan yang kuat memiliki keinginan untuk memperoleh hasil yang sukses yang direalisasikan dengan keikutsertaan dalam proses terapi, pelaksanana tugas tugas dan menginternalisasikannya pada dirinya.

Hasil penelitian lain yang dilakukan oleh Senécal, Noumen, dan White (2000) menemukan bahwa adanya efikasi diri pada penderita diabetes mellitus berperan penting dalam meningkatkan kontrol terhadap penyakit diabetes mellitus itu sendiri, yang pada gilirannya akan berdampak pada menurunnya gejalagejala diabetes mellitus. Lebih lanjut disampaikan bahwa efikasi diri (yaitu keyakinan pada kemampuan diri dalam menjaga kondisi kesehatan dengan menjalankan diet, olahraga, relasasi, pola pikir, dan konsumsi obat) merupakan upaya untuk meningkatkan kualitas hidup pasien. Oleh karena itu dapat dikatakan bahwa untuk mencapai suatu perubahan menuju hal yang lebih baik, dalam hal ini kualitas hidup yang lebih baik, sangat diperlukan adanya efikasi diri yang cukup dalam diri individu tersebut. Tanpa adanya efikasi diri yang cukup, maka akan melemahkan motivasi individu untuk berubah menuju kondisi yang lebih baik (Linley \& Joseph, 2004).

Tidak adanya keselarasan antara tugas-tugas yang dilakukan individu dengan manfaat tugas-tugas tersebut, serta perasaan belum mampu sepenuhnya dalam melaksanakan tugas dalam kehidupan sehari hari, akan menjadikan dampak terapi yang diperoleh juga kurang maksimal. Namun apabila subjek penelitian dapat menyelaraskan antara tugas-tugas selama proses terapi dengan kedalaman nilai yang akan diperoleh dari tugas-tugas, serta dapat terus melaksanakan tugas-tugas tersebut, maka akan menjadikan dirinya sebagai terapis bagi dirinya sendiri. Selanjutnya kualitas hidup cenderung dapat lebih baik.

\section{SIMPULAN DAN SARAN}

\section{Simpulan}

Pemberian perlakuan berupa terapi, terapi emotif, serta terapi perilaku berpengaruh terhadap kualitas hidup penderita diabetes millitus. Hal ini berarti bahwa pemberian terapi kognitif, terapi emotif serta terapi perilaku berupa diet diabetes, olahraga, konsumsi obat, dan periksa kedokter, berpengaruh terhadap terjadinya peningkatan kualitas hidup penderita diabetes millitus pada kelompok subjek penelitian.

Terdapat perbedaan yang signifikan pada kualitas hidup penderita diabetes millitus antara kelompok eksperimen dan kelompok kontrol setelah pemberian perlakuan terapi kognitif, terapi emotif, dan terapi perilaku berupa diet diabetes, olahraga, konsumsi obat, dan periksa ke dokter. 


\section{Saran}

Peneliti selanjutnya disarankan untuk mempertimbangkan kembali faktor motivasi dari subjek penelitian karena hal ini akan berpengaruh pula pada kedisiplinan subjek penelitian terhadap tugas-tugas yang harus dijalani apabila subjek diharuskan melakukan tugas-tugas secara mandiri di rumah.

Selain itu juga walaupun penelitian ini melaksanakan tahap monitoring empat hari sekali, ternyata tidak dapat sepenuhnya mengeliminasi dampak terkait tidak dilaksanakannya tugas tugas oleh subjek secara mandiri. Peneliti selanjutnya diharapkan dapat memberikan support lebih besar dengan monitoring dengan frekuensi lebih sering lagi. Selain itu peneliti selanjutnya diharapkan dapat juga memberikan informasi pada pihak keluarga sebagai support group untuk selalu mengingatkan, menemani, mendampingi subjek dalam menjalankan tugas-tugas, karena dari hasil interview salah satu alasan subjek tidak melakukan tugas tersebut karena dukungan keluarga sangat kurang.

\section{DAFTAR PUSTAKA}

Corey, G. (1988). Teori Dan Praktik Konseling Psikoterapi (cetakan pertama). Bandung: PT. ERESCO.

Davison, Neale., dkk. (2004). Psikologi Abnormal (Edisi 9). Jakarta: Rajawali Pers.
Dryden, W. \& Neenan M. (2003a). Essential Rational Emotive Behaviour Therapy. Wiley.

Dryden W. \& Neenan M. (2003b). The REBT Terapist's Pocket Companion Albert Ellis Institute: New York.

Egbochuku, EO. (2008). Efficacy of Rational-Emotive Behaviour Therapy on the Reduction of Test Anxiety Among Adolescents in Secondary Schools. European Journal of Social Sciences, 6(4).

Ellis, A. (1997). Using Rational Emotive Behavior Therapy Techniques to Cope with Disability. Professional Psychology: Research and Practice, 28 (1), 17.

Ellis, A. (2003). Early Theories and Practices of Rational Emotive Behavior Theory and How They Have Been Augmented and Revised During The Last Three Decades. Journal of Rational-Emotive \& Cognitive-Behavior Therapy, 21 (3/4).

Freedman, M. (2009). Anger Management: A Cognitive Behavioral Group Intervention Protocol for Students with Exceptional Learning Needs. The Center for School Mental Health at the University of Maryland.

Gibson, R., Mitchell. (2011). Bimbingan dan Konseling (Edisi ketujuh). Jakarta: Pustaka Pelajar. 
Goodridge, D., Trepman, E., \& Embil, J. M. (2005). Health-Related Quality of Life in Diabetic Patients with Foot Ulcers: Literature Review. Journal of Wound Ostomy \& Continence Nursing, 32(6), 368.

Grigg, A., Thommasen, H. V., Tildesley, H., \& Michalos, A. C. (2006). Comparing Self-Rated Health, Satisfaction and Quality of Life Scores between Diabetics and Others Living in the Bella Coola Valley. Social Indicators Research, 76(2), 263-281.

Hartati, T. (2003). Kualitas hidup Pender ita DM Tipe 2: Perbandingan Antara Penderita Kadar Gula Darah Terkendali Dan Tidak Terkendali. Tesis. Yogyakarta: Program Pascasarjana Fakultas Psikologi Universitas Gajah Mada. Yogyakarta.

Hastjarjo, D. (2008). Ringkasan Buku Cook \& Campbell. Universitas Gajah Mada. Yogyakarta.

Kazdin, A. E. (1995). Preparing and Evaluating Research Reports. Psychological Assessment, 7(3), 228.

Kabar Bisnis. (2010). Rendahnya Kepedulian Masyarakat Terhadap Diabetes. Diakses tanggal 20 November 2010 dari www.kabarbisnis.com/ $\mathrm{read} / 2816201$.

Kompas. (2008). Waspadai Ancaman Diabetes Mellitus. Diak- ses tanggal 15 Agustus 2009 dari http://www.kompas.com/read/ xml/2008/11/13/16094125.

Leod, M. (2006). Pengantar Konseling Teori dan Studi Kasus. Edisi Ketiga. Kencana Prenada Media Group

Linley, P. A., \& Joseph, S. (Eds.). (2004). Positive Psychology in Practice. New Jersey: Wiley.

Mc Cranty, R., Atkinson, M., \& Lipsenthal, L. (2000). Emotional Self Regulation Program Enhances Psychological Health and Quality of Life in Patients with Diabetes. HeartMath Research Center. No. 00-006, 1-11.

Rose, M., Fliege, H., Hildebrandt, M., Schirop, T., \& Klapp, B. F. (2002). The Network of Psychological Variables in Patients with Diabetes and Their Importance for Quality of Life and Metabolic Control [Electronic version]. Diabetes Care, 25(1), 35-42.

Sarafino, E. P.(1997). Health Psychology. Biopsychosocial Interactions. New York: John Wiley \& Sons.

Senecal, C., Noumen, A \& White, D. (2000). Motivation and Dietary Self Care in Adults With Diabetes: Are Self Efficacy and Autonomous Self Regulation Complementary or Competing Constructs. Health Psychology. 19 (5), 452-457. 
Shahab, A. (2006). Diagnosis dan Penatalaksanaan Diabetes Melitus (disarikan dari Konsensus Pengelolaan Diabetes Melitus di Indonesia: Perkeni 2006). Subbagian Endokrinologi Metabolik, Bagian Ilmu Penyakit Dalam, FK Unsri/ RSMH Palembang.

Shen, W., Kotsanos, J.G., Hutser, W.J., Mathias, S.D., Andrejasich, C.M.,\& Patrik D.L. (1999). Development and Validation of the Diabetes Quality of Life Clinical Trial Questionare. Medical care; 37(4), Lilly Suplement: Global Health Outcomes Research and Costumer Aplications AS45-66.S

Sharma, N. (2007). Psichososial Rehabilitation Treatment Methods Leading To Improvement in Quality Of Life And Disability In Psychiatric Patients. Journal Fiji General Practictioner ISN 1992-0334 volume 15, 7-10

Sharma, Sharma, R. (2007). Types of Psychological Treatments. Journal Fiji General Practictioner, 15, 15-18.

Solli, O., Stavem, K., \& Kristiansen, I. S. (2010). Health-Related Quality of Life in Diabetes: The Associations of Complications with EQ-5D Scores. Health and Quality of Life Outcomes, 8(1), 18.
Spiegler D Michael, Guevremont C. David. (2010). Contemporary Behavior Therapy Fifth Edition. Wadsworth. 10 Davis Drive Belmont, CA 94002-3098. USA.

Soegondo, S., Sukardji, K. (2008). Hidup Secara Mandiri dengan Diabetes Melitus, Kencing Manis, Sakit Gula: Bab VI Kegiatan Jasmani atau Olahraga Untuk Pengendalian Diabetes. Jakarta: Balai Penerbit Fakultas Kedokteran Universitas Indonesia.

Suryani, L. K. (2000). Menemukan Jati Diri Dengan Meditasi. Elex Media Komputindo. Jakarta.

Taylor, S. E., \& Stanton, A. L. (2007). Coping Resources, Coping Processes, and Mental Health. Annu. Rev. Clin. Psychol., 3, 377-401.

Wildes, K.R., Greisinger, A., O'Malley, K.J. (2003). Measurement in Practice: Review of Quality of Life Measures for Patient with Diabetes. United Stated Department of Veterans Affair. www.va.gov. diakses tgl. 10/05/2010. 